\title{
Artificial cold-adapted microbial mats cultured from Antarctic lake samples. 2. Short-term temperature effects on oxygen turn-over
}

\author{
Olivier Pringault", Evelyne Buffan-Dubau, Rutger de Wit** \\ Station Marine d'Arcachon Laboratoire d'Océanographie Biologique CNRS-UMR 5805 Université Bordeaux-1, \\ 2 rue du Prof. Jolyet, 33120 Arcachon, France
}

\begin{abstract}
Short-term temperature effects on oxygen turn-over in artificial cold-adapted microbial mats were experimentally studied using microsensor techniques. The artificial mats were cultured in benthic gradient chambers under opposing oxygen and sulphide gradients, and community metabolism was analysed after 8 mo of incubation at $5^{\circ} \mathrm{C}$. Microbial mat samples from Lake Fryxell (Antarctica) were used as inocula. Both net and gross $\mathrm{O}_{2}$ productivity were maximal at $10^{\circ} \mathrm{C}$, whereas gross $\mathrm{O}_{2}$ production was completely inhibited at $15^{\circ} \mathrm{C}$. Thus, the microbial community exhibited a psychrophilic response. Nevertheless, the inhibition of oxygenic photosynthesis at $15^{\circ} \mathrm{C}$ might result from indirect effects of accumulation of $\mathrm{H}_{2} \mathrm{~S}$ in the photic zone, which might induce the inhibition of photosystem II activity. The dynamics of the dark and light net metabolism of $\mathrm{O}_{2}$ were estimated from transient oxygen profiles. They were strongly affected by the temperature changes, exhibiting temperature characteristics well above those calculated from the steady-state approaches. This indicates that indirect effects of temperature probably occurred, i.e. (1) migration of microorganisms locally resulting in higher biomass, (2) an increase of the oxygen requirements for the oxidation of reduced compounds such as $\mathrm{H}_{2} \mathrm{~S}$, or both. The results show that the metabolic rates of the different functional groups in these artificial microbial mats were fine-tuned to the prevailing temperature. This resulted in a close coupling of oxygen and sulphur cycles as has been previously found for mesophilic hypersaline mats.
\end{abstract}

KEY WORDS: Microsensors · Photosynthesis · Respiration · Psychrophilic community $\cdot$ Lake Fryxell

\section{INTRODUCTION}

Microbial mats have been defined as vertically laminated structures developing in the superficial sediment layers and on solid surfaces (van Gemerden 1993). They are characteristically dominated by different functional groups of microbes, including oxygenic phototrophs (comprising microalgae and cyanobacteria), aerobic heterotrophic bacteria, chemotrophic sulphur bacteria, phototrophic sulphur bacteria and sulphate-

\footnotetext{
*Present address: Centre IRD de Nouméa, BP A5, 98848 Nouméa Cedex, New Caledonia

${ }^{* *}$ Corresponding author.

E-mail: r.de-wit@epoc.u-bordeaux.fr
}

reducing bacteria. Due to their structure and organisation, microbial mats are an ideal model system to study the biochemical conversion of organic matter in sediments (Canfield \& Des Marais 1993). Microbial mats develop under a wide range of environmental conditions. They can be observed in freshwater systems (van Gemerden 1993), intertidal marine sediments (van Gemerden et al. 1989, Epping et al. 1999) or in hypersaline lagoons (Jørgensen \& Cohen 1977). Moreover, microbial mats particularly form under extreme conditions of temperature, which have been described in arid hot deserts (Johansen 1993), sulphidic hot springs (Pierson et al. 1987) and in the permanently cold environment of the polar regions, especially in Antarctica (Vincent et al. 1993, Hawes \& Schwarz 1999). 
Light and temperature are among the major factors that govern metabolic process rates in general and therefore also the primary production and respiration of phototrophic communities. In Antarctica, there is increasing evidence of temperature increase and enhancement of ultraviolet B flux through the ozone hole (Wynn-Williams 1996). Whereas many studies have addressed the effects of UV radiation on the structure and the productivity of sea ice communities (Vincent et al. 1993, Quesada et al. 1995, WynnWilliams 1996, Nadeau et al. 1999), little is known about the consequences of temperature changes on the microphytobenthic communities. Psychrophilic and psychrotrophic strains have been described for most of the functional groups that classically inhabit a microbial mat, including phototrophic microorganisms (Tang et al. 1997, Madigan et al. 2000), and aerobic and anaerobic chemoorganoheterotrophic bacteria (Isaksen \& Jørgensen 1996, Mountfort et al. 1997, Knoblauch et al. 1999). However, it remains unknown whether psychrophiles dominate in Antarctic microbial mat communities or whether they only constitute a minority. A recent study of culturable strains (Tindall et al. 2000) supports the latter hypothesis for the aerobic organoheterotrophs in the mat samples from Lake Fryxell, Antarctica. Nevertheless, the temperature optimum of community metabolism is not a simple average of the physiological temperature optima of the individual members, but is also determined by the complex interactions observed within a microbial mat (van den Ende \& van Gemerden 1994). A recent study has shown that photosynthesis in an Antarctic cyanobacterial biofilm was optimal well above the in situ temperature (Nadeau \& Castenholz 2000). Using microsensor techniques, the effects of temperature on the oxygen and sulphide turn-over in mesophilic hypersaline microbial mats have been described in detail (Epping \& Kühl 2000, Wieland \& Kühl 2000). These studies demonstrated that the responses of microbial mats to short-term changes in temperature were extremely complex due both to the tight coupling between the production and consumption and to the strong interactions occurring between the carbon, the oxygen and the sulphur cycles. On the basis of these studies in mesophilic environments, we anticipated that coupling of biogeochemical cycles is also an important regulating factor for temperature effects in microbial mats originating from polar regions.

The aim of the present study was to assess the shortterm response of oxygen community metabolism to changes of temperature in an artificial cold-adapted microbial mat. For that purpose, benthic gradient chambers (BGC) (Pringault et al. 1996) were used for experimental culturing of artificial mats from inocula of Antarctic lake microbial mats. The oxygen turn-over rates were measured using microsensor techniques, and variations of oxygen and hydrogen sulphide depth profiles were monitored at different temperatures. The formation and structure of the experimental biofilms were studied in detail by Buffan-Dubau et al. (2001, this issue).

\section{MATERIALS AND METHODS}

Experimental conditions. Experimental microbial mats were cultured in BGC (Pringault et al. 1996) from inocula $(10 \% \mathrm{v} / \mathrm{v}$ mixed into the top $1 \mathrm{~cm})$ originating from natural microbial mats sampled in Lake Fryxell (Antarctica). Further details of the sampling site, mat sample collection and preservation, as well as culturing procedure are described in Buffan-Dubau et al. (2001). In the present study, we used the Mat 2 described by Buffan-Dubau et al. (2001). The mat was $8.5 \mathrm{mo}$ old and was cultured at $5^{\circ} \mathrm{C}$. At the end of the culturing period, the BGC was opened, and $\mathrm{O}_{2}$ and $\mathrm{H}_{2} \mathrm{~S}$ microsensors were gently inserted into the mat without disturbing the structure to perform the profile measurements.

Oxygen and hydrogen sulphide concentration profiles and the rates of oxygen community metabolism were measured at $0,5,10$ and $15^{\circ} \mathrm{C}$. The artificial mat was exposed to the defined temperature for 24 to $36 \mathrm{~h}$, which was the minimum time required to achieve the whole set of measurements. Between each experiment at the different temperatures, the mat was set back and maintained at the culturing temperature (i.e. $5^{\circ} \mathrm{C}$ ) for 24 to $48 \mathrm{~h}$. The oxygen and hydrogen sulphide depth profiles were then measured to check whether the changes caused by temperature were reversible. During the entire experiment, the micromanipulator was maintained at the same reference position. This way, all measured profiles exactly corresponded to the same position in space. The experiments reflected a precise measurement of temperature effects on profiles and processes for that particular spot. Therefore, the measurements were not influenced by the spatial heterogeneity of the mat (Buffan-Dubau et al. 2001). During measurement, light was provided from the same source as that used for the culturing (i.e. incandescent lamp); the photosynthetic active radiation (PAR) was $70 \mu \mathrm{mol}$ photons $\mathrm{m}^{-2} \mathrm{~s}^{-1}$ at the mat surface.

Microsensors measurements. Oxygen concentrations were measured with a Clark-type $\mathrm{O}_{2}$ microelectrode (Revsbech 1989). The response time was less than $1 \mathrm{~s}$ and the stirring sensitivity was around $1 \%$. Two-point calibrations were performed using the procedure described by Revsbech \& Jørgensen (1986). Oxygen partial pressures were converted to concen- 
trations as a function of salinity and temperature (Garcia \& Gordon 1992). From steady-state profiles, the net productivity (NP) of oxygen was calculated from the linear oxygen gradient in the diffusive boundary layer (DBL) according to Kühl et al. (1996), i.e. a positive flux indicated a net export of oxygen from the mat to the overlying water, the mat acting as source for oxygen, whereas a negative flux indicated that the mat acted as a sink for oxygen.

Depth profiles of gross $\mathrm{O}_{2}$ production rates were measured with a vertical resolution of 100 to $200 \mu \mathrm{m}$ using the standard light-dark (L-D) shift technique (Revsbech \& Jørgensen 1983). Areal gross photosynthesis (AGP) corrected for porosity was then calculated by integrating the photosynthesis profiles. The microbial mat developed as a roughly 2.5 to $5 \mathrm{~mm}$ thick organic matrix on top of the sandy sediment (BuffanDubau et al. 2001). It has been found that a substantial part of phototrophic biofilms consists of intact cells with intracellular water; a precise estimation of the porosity by standard drying procedures is thus difficult (Canfield \& Des Marais 1993). Therefore, we have used an average porosity of $0.8(\mathrm{v} / \mathrm{v})$, which is a typical value observed in the top $1 \mathrm{~mm}$ of microbial mats with high amounts of exopolysaccharides (Wieland \& Kühl 1999, Epping \& Kühl 2000). $\mathrm{H}_{2} \mathrm{~S}$ concentration profiles were measured with a $\mathrm{H}_{2} \mathrm{~S}$ microsensor (Kühl et al. 1998). Calibration procedures have been previously described by Pringault et al. (1998).

The temperature dependence of the different metabolic processes was characterised by calculating the apparent activation energy $\left(E_{\mathrm{a}}\right)$ and the corresponding temperature coefficient $\left(Q_{10}\right)$ value according to Isaksen \& Jørgensen (1996). $E_{a}\left(\mathrm{~J} \mathrm{~mol}^{-1}\right)$ was determined from the slope of an Arrhenius plot:

$$
\ln (k)=\ln (\mathrm{A})+\left[-E_{\mathrm{a}} \times(\mathrm{R} \times T)^{-1}\right]
$$

where $k$ is the process rate, $\mathrm{A}$ is the Arrhenius constant, $\mathrm{R}$ is the gas constant $\left(8.3144 \mathrm{~J} \mathrm{~K}^{-1} \mathrm{~mol}^{-1}\right)$ and $T$ is the absolute temperature $\left({ }^{\circ} \mathrm{K}\right) . Q_{10}$ was calculated between 0 an $10^{\circ} \mathrm{C}$ with the following equation:

$$
Q_{10}=\exp \left\{E_{\mathrm{a}} \times 10 \times[\mathrm{R} \times T \times(T+10)]^{-1}\right\}
$$

Dynamics of dark oxygen respiration and light net oxygen metabolism (net result of production and respiration) were calculated by a recently developed technique. Accordingly, $\mathrm{O}_{2}$ concentrations were monitored during short dark-light (D-L) cycles, and this procedure was repeated sequentially at different depths. It was checked that the $\mathrm{O}_{2}$ concentration returned to the same value after completion of the DL cycle. Preliminary observations showed that full reversibility was achieved when a 20 min dark period was followed by a 40 min light period. Hence, this regimen was adopted and measurements were repeated at a vertical depth resolution of $200 \mu \mathrm{m}$, starting below the maximum depth of oxygen penetration up to $1 \mathrm{~mm}$ above the mat surface. From this series of measurements it was, therefore, possible to deduce the transient state depth profiles of $\mathrm{O}_{2}$ during a L-D cycle. The transient rates of dark $\mathrm{O}_{2}$ respiration and light net $\mathrm{O}_{2}$ metabolism were calculated at different depths from the numerical solution of the differential equations according to the second Fick's diffusion law (Epping et al. 1999):

$$
\frac{\mathrm{d} C(z, t)}{\mathrm{d} t}=D_{s} \frac{\mathrm{d}^{2} C(z, t)}{\mathrm{d} z^{2}}+P(z, t)-R(z, t)
$$

where $C$ represents the $\mathrm{O}_{2}$ concentration, $z$ the depth, $t$ the time, $D_{\mathrm{s}}$ the sedimentary diffusion coefficient of $\mathrm{O}_{2}, P$ the $\mathrm{O}_{2}$ production and $R$ the $\mathrm{O}_{2}$ respiration rates expressed per unit of pore water volume. For $D_{\mathrm{s}}$, a constant value with depth was assumed that equals $50 \%$ of the diffusion coefficient in water, $D_{0}$. $D_{0}$ coefficients were calculated as a function of temperature and salinity according to Broeker \& Peng (1974). Data acquisition and calculation procedures have been described by Epping et al. (1999). For each D-L cycle, oxygen concentration was recorded at a frequency of 1 every 5 s. A total of 720 transient $\mathrm{O}_{2}$ profiles were determined.

\section{RESULTS}

\section{Steady-state solute profiles and depth distribution of gross photosynthesis}

In the dark, maximum depths of oxygen penetration varied from 0.6 to $0.2 \mathrm{~mm}$ (Fig. 1). Exposure to light resulted in oxygen accumulation below the mat surface, between 0 and $1 \mathrm{~mm}$ depth. Results were different for $15^{\circ} \mathrm{C}$, where the light profile showed that the mat was still acting as an oxygen sink and not as an oxygen source (Fig. 1). Oxygen peaks were maximal at $10^{\circ} \mathrm{C}$ with values of ca $300 \%$ of air saturation, corresponding to $1000 \mu \mathrm{M}$ of dissolved $\mathrm{O}_{2}$. The maximum depth of $\mathrm{O}_{2}$ penetration decreased with temperature from $3.2 \mathrm{~mm}$ at $0^{\circ} \mathrm{C}$ to $0.8 \mathrm{~mm}$ at $15^{\circ} \mathrm{C}$. From 0 to $10^{\circ} \mathrm{C}$, volumetric rates of gross photosynthesis increased with temperature, but at $15^{\circ} \mathrm{C}$ photosynthesis was not detectable (Fig. 1). The maximum gross $\mathrm{O}_{2}$ production was observed at the same depth horizon, i.e. $0.6 \mathrm{~mm}$,

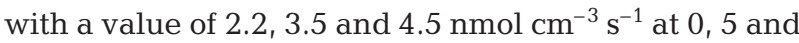
$10^{\circ} \mathrm{C}$, respectively. For this temperature range, the thickness of the photic zone was 0.8 to $1.0 \mathrm{~mm}$ independent of temperature.

In the dark, $\mathrm{H}_{2} \mathrm{~S}$ reached the mat surface (Fig. 2), and low concentrations of $\mathrm{H}_{2} \mathrm{~S}$ were measured in the DBL above the sediment. This shows that the sulphide 


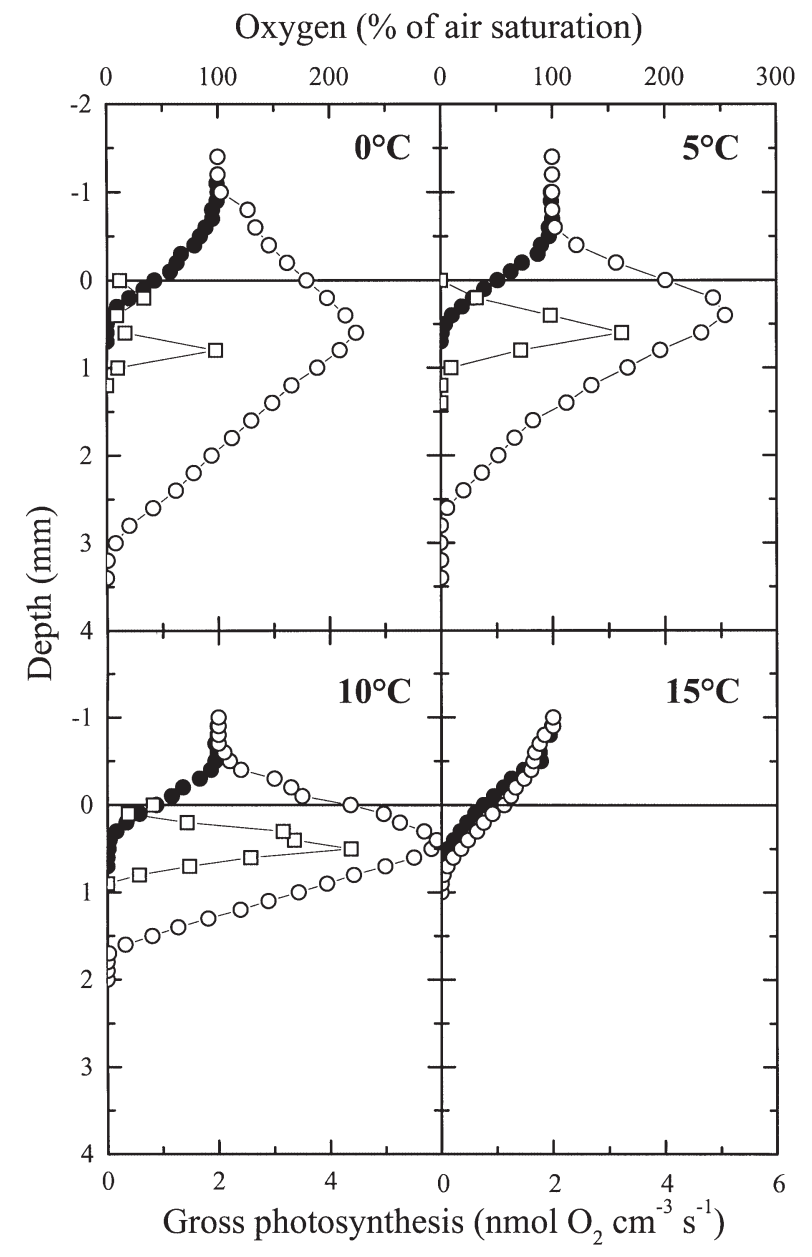

Fig. 1. Averaged steady-state profiles $(\mathrm{n}=3)$ of oxygen under dark ( ) and light (O) exposures and the corresponding gross photosynthesis $(\square)$ profiles in the artificial microbial mat incubated at different temperatures

consumption in the mat was not sufficient to counterbalance the sulphide input by both diffusion from below the mat and sulphate reduction in the mat. Light exposure at 0,5 and $10^{\circ} \mathrm{C}$ resulted in the complete disappearance of $\mathrm{H}_{2} \mathrm{~S}$ in the first millimetres of the mat, meaning that the photic zone became free of sulphide (Fig. 2). In contrast, at $15^{\circ} \mathrm{C}$, light exposure had only a very minor impact on the $\mathrm{H}_{2} \mathrm{~S}$ profile, and even at the end of the light period most of the photic zone was still exposed to $\mathrm{H}_{2} \mathrm{~S}$.

\section{Steady-state oxygen metabolism at different temperatures}

AGP and NP were plotted as a function of temperature (Fig. 3). From 0 to $10^{\circ} \mathrm{C}$, both activities increased with temperature, from 3.40 to $8.68 \mathrm{nmol} \mathrm{cm} \mathrm{cm}^{-2}$ for
AGP and from 2.37 to $7.29 \mathrm{nmol} \mathrm{cm}^{-2} \mathrm{~min}^{-1}$ for NP. The maximal values were measured at $10^{\circ} \mathrm{C}$, which is above the culturing temperature (i.e. $5^{\circ} \mathrm{C}$ ). The apparent $E_{\mathrm{a}}$ from 0 to $10^{\circ} \mathrm{C}$ were equal to $60.4 \mathrm{~kJ} \mathrm{~mol}^{-1}$ and $72.4 \mathrm{~kJ} \mathrm{~mol}^{-1}$ for AGP and NP, respectively. These values corresponded to a $Q_{10}$ of 2.6 and 3.1, respectively. Exposure to $15^{\circ} \mathrm{C}$ was critical for the oxygen production in the mat, as no gross production was detectable and negative values were measured for NP $\left(-2.28 \mathrm{nmol} \mathrm{cm}^{-2} \mathrm{~min}^{-1}\right)$. This shows that the mat switched from a net autotrophic mode to a fully heterotrophic mode.

Similarly, oxygen consumption flux was measured in the dark at the different temperatures (Fig. 3). From 0 to $10^{\circ} \mathrm{C}$, activities also increased from 2.62 to $3.77 \mathrm{nmol}$ $\mathrm{cm}^{-2} \mathrm{~min}^{-1}$ for the oxygen uptake. Again, the maximum rate was observed at $10^{\circ} \mathrm{C}$, which was above the culturing temperature, and exposure to $15^{\circ} \mathrm{C}$ gave rise to a strong decrease. The apparent $E_{\mathrm{a}}$ of dark $\mathrm{O}_{2}$ uptake (from 0 to $10^{\circ} \mathrm{C}$ ) was $23.4 \mathrm{~kJ} \mathrm{~mol}^{-1}$, corresponding to a $Q_{10}$ of 1.4 .

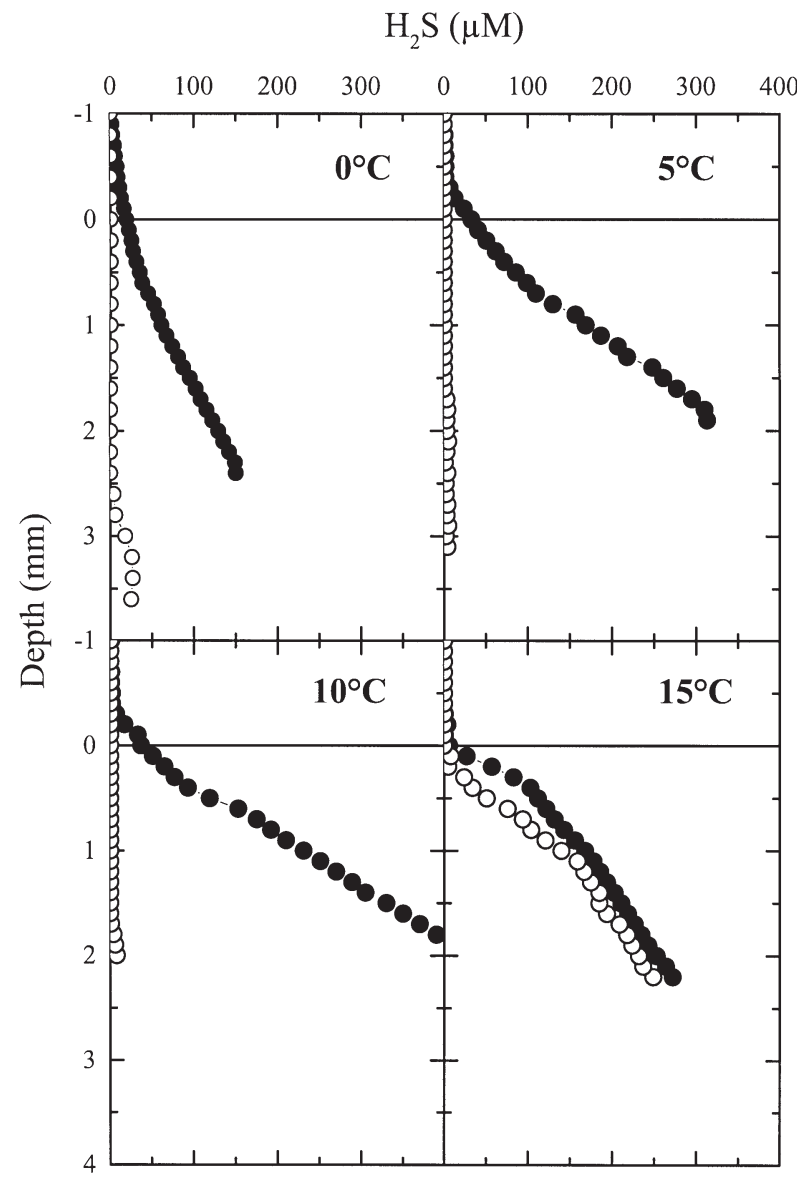

Fig. 2. Averaged steady-state profiles $(n=3)$ of $\mathrm{H}_{2} \mathrm{~S}$ under dark (@) and light (O) exposures in the artificial microbial mat incubated at different temperatures 

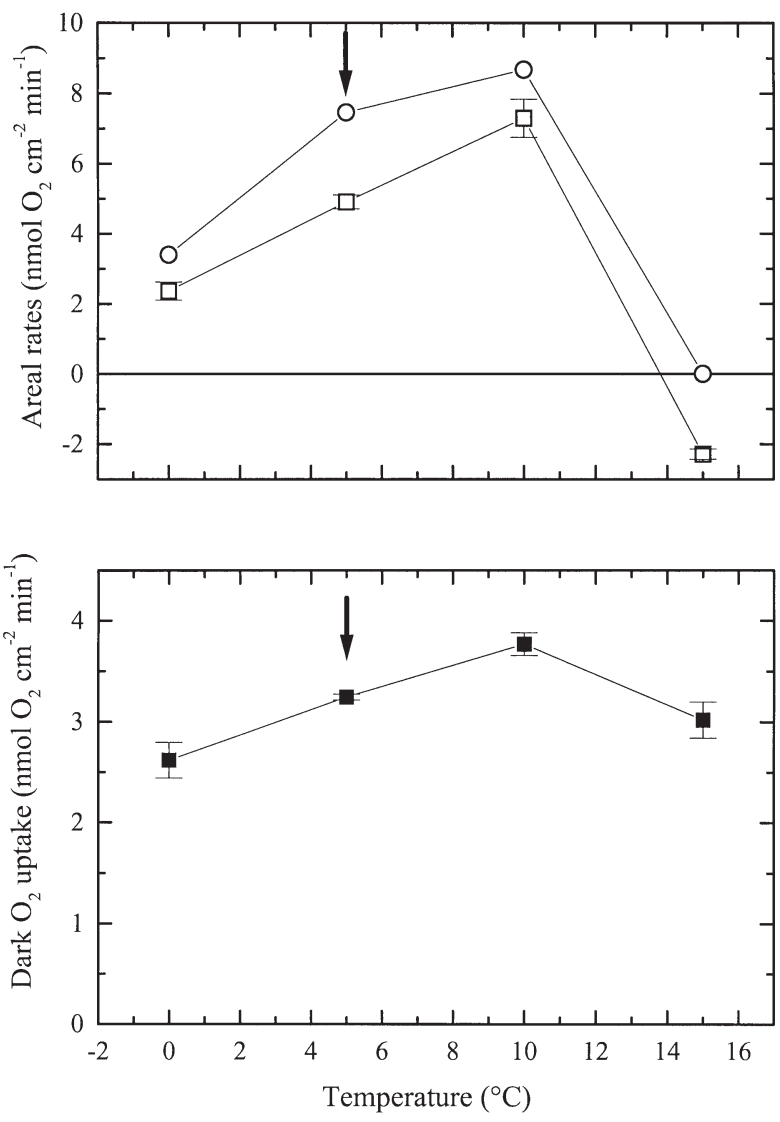

Fig. 3. Temperature effects on net productivity $(\square)$, gross photosynthesis (O) and dark $\mathrm{O}_{2}$ uptake ( $\mathbf{\square}$ ) in the artificial microbial mat. Areal rates were calculated from the data presented in Fig. 1. The arrows indicate the temperature originally used for culturing the mat. Error bars are \pm 1 SD $(n=3)$

\section{Transient dynamics of oxygen metabolism and temperature effects}

The short D-L cycling experiments (cf. 'Materials and methods') allowed a detailed description to be obtained of the dynamic changes of oxygen community metabolism occurring shortly after shifting between light and dark. The variables comprised the dark $\mathrm{O}_{2}$ respiration and the net $\mathrm{O}_{2}$ production rate, which were calculated during the dark and light periods, respectively (cf. 'Materials and methods'). Temperature strongly affected the dark respiration distribution. At 0,5 and $10^{\circ} \mathrm{C}$, the profiles of dark $\mathrm{O}_{2}$ respiration exhibited 2 distinct layers: an upper zone associated with the photic zone observed in the light and a deeper zone overlying the oxic-anoxic interface where reduced compounds could be oxidised (Fig. 4). The evolution in time and depth of these 2 zones was strongly affected by the increase of temperature. At $0^{\circ} \mathrm{C}$, respiration rates and the thickness of both layers were almost constant with time, whereas at $10^{\circ} \mathrm{C}$, the dynamics of both respiration zones were very marked. At the latter temperature, dark respiration in the upper layer decreased with time and the peak moved slightly upwards to the sediment surface (Fig. 4). In the deeper layer, the dark respiration rate strongly decreased with time and the peak also migrated upwards. At the end of the dark exposure, the upper part of the mat was still active, whereas the deepest respiration layer completely disappeared. At $15^{\circ} \mathrm{C}$, respiration was very low, maximum rates were below

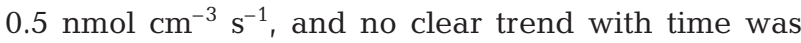
observed (Fig. 4).

Since the $10^{\circ} \mathrm{C}$ incubation of the mat induced both an initial strong stimulation of the volumetric rates of dark $\mathrm{O}_{2}$ respiration and a marked dynamic time course, these results are detailed in Fig. 5. At $0^{\circ} \mathrm{C}$, after 20 min of darkness, oxygen concentrations were still high in the photic $(0.6 \mathrm{~mm})$ and aphotic $(1.4 \mathrm{~mm})$ zones. In contrast, at $10^{\circ} \mathrm{C}$, oxygen completely disappeared after 18.3 and $13.7 \mathrm{~min}$ at $0.6 \mathrm{~mm}$ (photic zone) and $1.4 \mathrm{~mm}$ depths (aphotic zone), respectively (Fig. 5). This resulted in a sharp decrease of respiration, as soon as oxygen reached a limiting concentration. Thus, the strong decrease of oxygen concentration with time within the aphotic zone explained the decrease of the rates in the bottom respiration layer.

The depth distribution of net $\mathrm{O}_{2}$ production rates upon the shift from dark to light was also strongly affected by temperature (Fig. 6). Positive values indicated a net $\mathrm{O}_{2}$ production, whereas negative values indicated that $\mathrm{O}_{2}$ respiration exceeded photosynthetic $\mathrm{O}_{2}$ production. At 0 and $5^{\circ} \mathrm{C}$, a zone of net $\mathrm{O}_{2}$ production was observed close to the surface (Fig. 6) and, thus, in relation with the presence of the oxygenic phototrophic microorganisms (Buffan-Dubau et al. 2001). Deeper in the mat, respiration was taking place at a low rate. Under light exposure, at 0 and $5^{\circ} \mathrm{C}$, no clear variation with time was observed for the net $\mathrm{O}_{2}$ metabolism profile. In contrast, incubation at $10^{\circ} \mathrm{C}$ resulted in a completely different trend: the structure including 2 distinct zones was also present; however, both layers were tightly coupled with regard to their evolution with time (Fig. 6). The net production of $\mathrm{O}_{2}$ (upper layer) increased with time and concomitantly the respiration zone (lower layer) exhibited an increase of the rates together with an increase of the layer thickness. As previously observed for the respiration, dynamics of net $\mathrm{O}_{2}$ metabolism were not very pronounced at $15^{\circ} \mathrm{C}$. No layer with net oxygen production was detected, and a relatively small peak of net $\mathrm{O}_{2}$ consumption was observed at ca 0.6 to $1 \mathrm{~mm}$ depth (Fig. 6). The maxi-

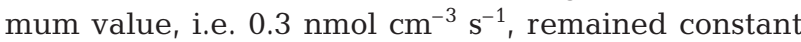
with time. 


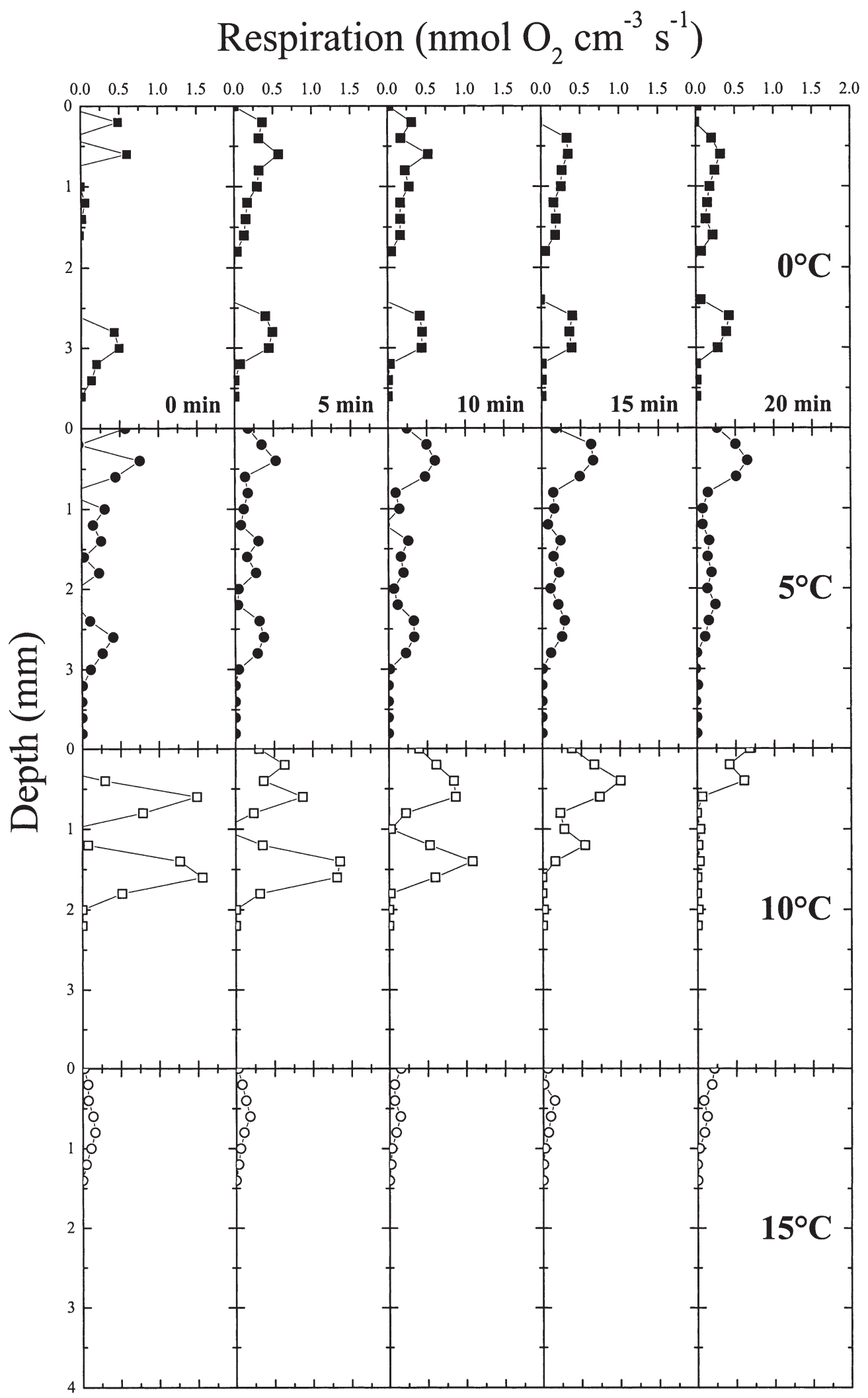

Fig. 4. Depth profiles of the dark oxygen respiration as a function of time in the artificial microbial mat incubated at different temperatures. Dynamics of the respiration were calculated from transient oxygen profiles measured during short dark-light cycles 


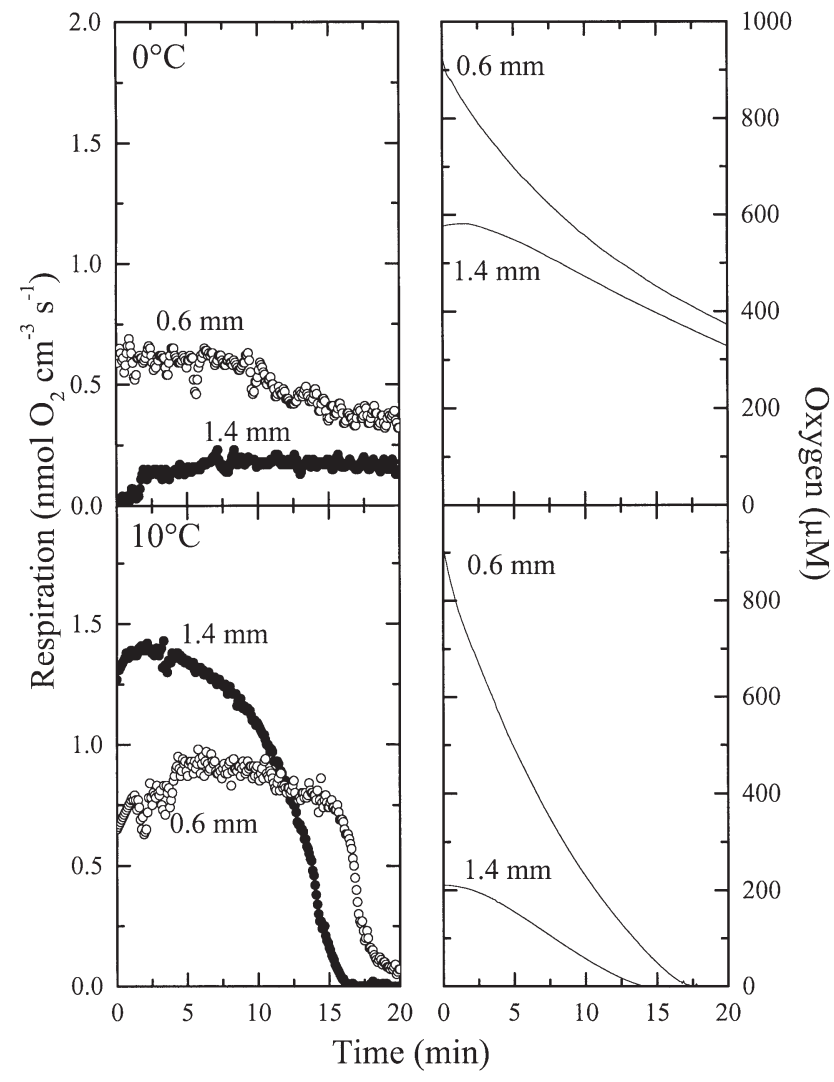

Fig. 5. Time course of oxygen consumption after darkening in the artificial microbial mat at 2 different depths: in the photic zone $(0.6 \mathrm{~mm})$ and in the aphotic zone $(1.4 \mathrm{~mm})$, for 0 and $10^{\circ} \mathrm{C}$ (left panels). The corresponding oxygen concentration evolution is also shown (right panels)

\section{DISCUSSION}

\section{Temperature effects on oxygen metabolism during steady states}

The different metabolic processes that affected the oxygen turn-over in the artificial cold-adapted microbial mat exhibited similar responses to short-term temperature changes; i.e. the rates increased from 0 to $10^{\circ} \mathrm{C}$, and a strong decrease of the activity was observed at $15^{\circ} \mathrm{C}$. However, at $15^{\circ} \mathrm{C}$ respiration was still active while oxygenic photosynthesis was totally inhibited. The oxygen community metabolism was thus psychrophilic, i.e. cold-loving, showing that the community involved in the oxygen cycle was adapted to the temperature used for culturing $\left(5^{\circ} \mathrm{C}\right)$. A possible explanation is that the artificial mat was dominated by psychrophilic microorganisms according to the definition of Morita (1975). For each metabolic process, the optimum temperature $\left(T_{\text {opt }}\right)$ was always around $10^{\circ} \mathrm{C}$, i.e. above the temperature used for the culturing $\left(5^{\circ} \mathrm{C}\right)$, although the determination of $T_{\text {opt }}$ would require more detailed measurements between 5 and $15^{\circ} \mathrm{C}$. It is well known that the temperature optimum of psychrophilic or psychrotrophic bacteria is often well above the in situ temperature of their natural habitats (Isaksen \& Jørgensen 1996, Tang et al. 1997, Fristen \& Priscu 1998, Knoblauch \& Jørgensen 1999). The natural mats from Lake Fryxell (Antarctica) used as inocula for the culturing of the artificial mats are exposed to temperatures below $10^{\circ} \mathrm{C}$ during the whole year (Buffan-Dubau et al. 2001). Therefore, we think that the mats from Lake Fryxell were a good source for psychrophilic and psychrotrophic microorganisms. The culturing at $5^{\circ} \mathrm{C}$ might have resulted in enhanced selection of psychrophiles. Nevertheless, the temperature response of the metabolic processes involved in the oxygen cycle might be also explained by a more efficient coupling between the different metabolic processes at the temperature optimum. Therefore, while efficient coupling of the metabolic processes prevents build-up of toxic intermediates, the observed suboptimal rates at higher temperature than the optimum one might be due to imbalance and negative feedback on rates of accumulated toxic products such as sulphide.

\section{Link between oxygen production and sulphur cycling}

The oxygen production was strongly affected by the incubation at $15^{\circ} \mathrm{C}$. Gross photosynthesis was fully inhibited and the mat switched from a net autotrophic mode to a fully heterotrophic mode (Fig. 3). Pigment signatures and microscopic observations showed that green microalgae and cyanobacteria inhabited the oxic layer (Buffan-Dubau et al. 2001). Cyanobacteria that form microbial mats in Arctic or Antarctic systems have been shown to be mostly psychrotrophs (Tang et al. 1997, Fritsen \& Priscu 1998), whereas microalgae from polar regions are generally considered to be psychrophiles (Smith et al. 1994). Moreover, a recent study showed that an Antarctica microbial mat inhabited by both psychrophilic and psychrotrophic cyanobacteria actively photosynthesised at temperatures from 2 to $20^{\circ} \mathrm{C}$, with maximum photoincorporation of carbon at $20^{\circ} \mathrm{C}$ (Nadeau \& Castenholz 2000). Therefore, the inhibition of gross photosynthesis at $15^{\circ} \mathrm{C}$ observed in our artificial mat may have been due to an indirect effect of temperature on oxygen production. Actually, at $15^{\circ} \mathrm{C}$, under light exposure, steady-state sulphide profiles showed that $\mathrm{H}_{2} \mathrm{~S}$ was still present in the photic zone with an average concentration of $60 \mu \mathrm{M}$ and a maximum of $140 \mu \mathrm{M}$ at $1 \mathrm{~mm}$ depth. $\mathrm{H}_{2} \mathrm{~S}$ is known to be very toxic for the photosystem II (PSII). The threshold concentra- 


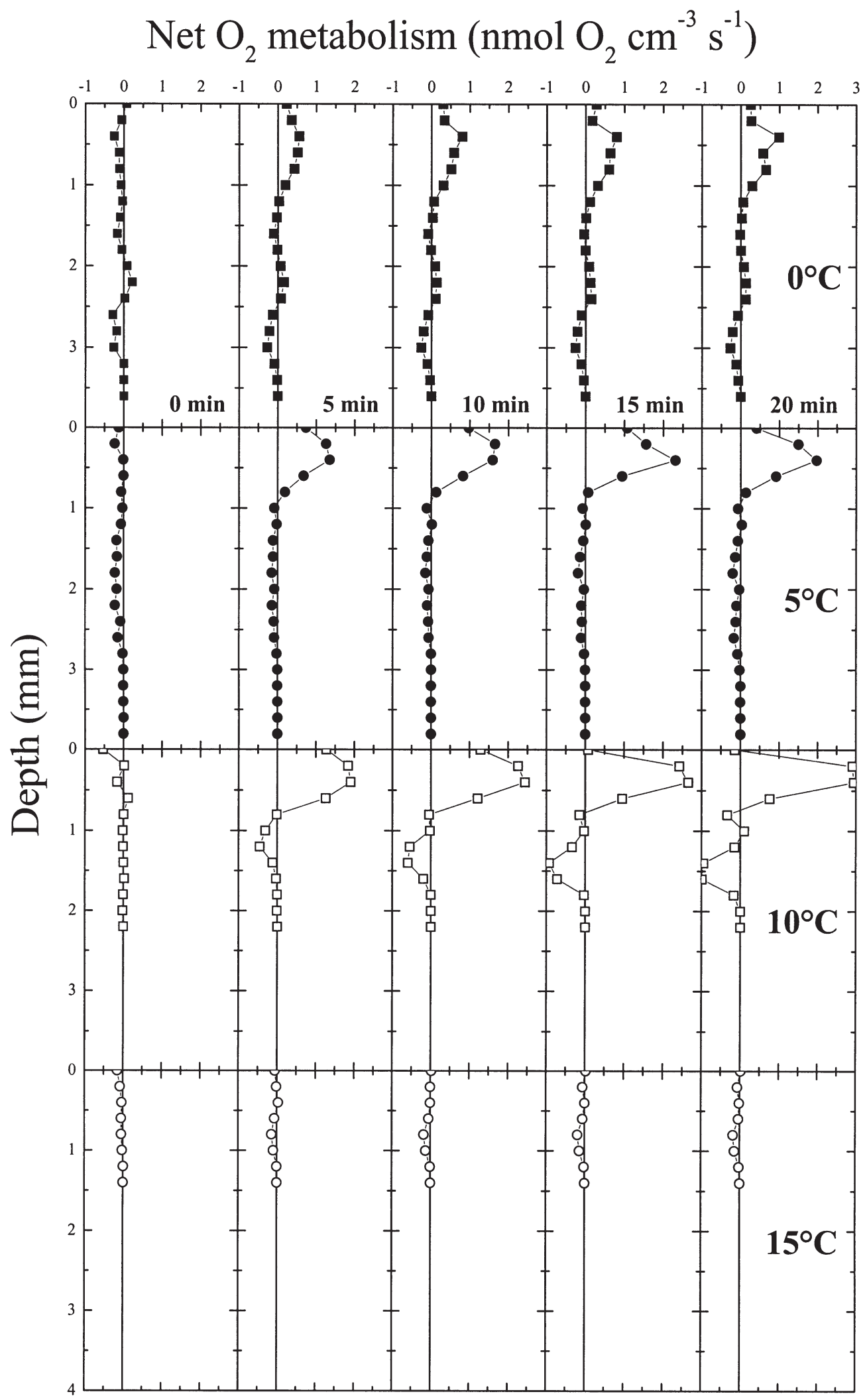

Fig. 6. Depth profiles of the net metabolism of oxygen as a function of time in the artificial microbial mat incubated at different temperatures. Positive values indicate a net oxygen production, whereas negative values indicate a net oxygen consumption. Dynamics of the net metabolism of oxygen were calculated from transient oxygen profiles measured during short dark-light cycles 
tion and the type of inhibition depend on the microorganism species (Cohen et al. 1986). It can therefore be hypothesised that the inhibition of gross photosynthesis was due to a sulphide effect and not to a psychrophilic response. The inhibition of PSII was clearly reversible since oxygenic photosynthesis was again taking place as soon as the mat was incubated under light to its in situ temperature, which led to a complete disappearance of $\mathrm{H}_{2} \mathrm{~S}$ in the photic zone.

Pigment analyses of the mat showed that the anoxic layer comprised phototrophic purple non-sulphur bacteria (Buffan-Dubau et al. 2001). It may seem surprising that we did not obtain a clear signal from phototrophic purple sulphur bacteria, despite the availability of hydrogen sulphide. However, this is consistent with previous results indicating that isolates of purple sulphur bacteria from cold environments grew very slowly at $4{ }^{\circ} \mathrm{C}$ and did not show specific adaptation to low temperatures (Herbert \& Tanner 1977). Thus, purple non-sulphur bacteria are apparently a more successful group at low temperatures. This is also consistent with a recent study reporting the presence of psychrophilic purple nonsulphur bacteria in Antarctic microbial mats (Madigan et al. 2000). Some representatives of the purple nonsulphur bacteria can oxidise sulphide to sulphur or sulphate, using photon radiation as an energy source (Imhoff 1995). Sulphide profiles at 0,5 and $10^{\circ} \mathrm{C}$ showed that sulphide oxidation was high during the light period (Fig. 2). This strong stimulation during the light period might reflect a direct role of sulphide photo-oxidation by purple non-sulphur bacteria and cyanobacteria, and also an indirect effect of photosynthetically produced oxygen as a substrate for chemotrophic sulphide oxidation by colourless sulphur bacteria. Thus, the major pathway of sulphide oxidation in the mat remains unknown. At $15^{\circ} \mathrm{C}$ the small difference between the dark and light $\mathrm{H}_{2} \mathrm{~S}$ profiles indicated that sulphide consumption was strongly inhibited both in the light and in the dark
(Fig. 2). Two possibilities can be envisioned. Firstly, if purple non-sulphur bacteria were the major sulphide oxidisers in the mat, their psychrophilic character would have inhibited sulphide oxidation at $15^{\circ} \mathrm{C}$, leading to accumulation of $\mathrm{H}_{2} \mathrm{~S}$ in the photic zone, which resulted in the inhibition of oxygen production. Secondly, if colourless sulphur bacteria were the predominant sulphide oxidisers in the mat, we can infer that either these bacteria were psychrophiles or that, alternatively, a direct inhibition of oxygen production at $15^{\circ} \mathrm{C}$ deprived these bacteria of their electron acceptor.

In conclusion, the psychrophilic response observed for oxygen production may have been due to (1) a direct inhibition of gross photosynthesis by the incubation at high temperature, (2) an inhibition of the PSII by $\mathrm{H}_{2} \mathrm{~S}$ accumulation in the photic zone or (3) a combination of both phenomena. Our conclusion is consistent with those previously reported for natural microbial mats in warm environments where oxygen production was strongly affected by sulphide production, which was enhanced by temperature increases (Wieland \& Kühl 1999, Epping \& Kühl 2000).

\section{Temperature dependence on reaction kinetics}

Temperature has a direct influence on the reaction kinetics of metabolic processes, which can be described by their $E_{a}$ and $Q_{10}$ values. Therefore, we have calculated the apparent $E_{\mathrm{a}}$ and $Q_{10}$ values for the different aspects of oxygen community metabolism in the artificial mat and compared those with values previously described for other benthic environments (Table 1). The temperature optimum, on which the terminology is based, is most often the privileged parameter in studies of cold adaptation, but $E_{\mathrm{a}}$ deserves more attention (Thamdrup \& Fleischer 1998). These authors have invoked a decrease of $E_{\mathrm{a}}$ as an efficient adaptation to low temperatures in cold-

Table 1. Apparent energy activation $\left(E_{\mathrm{a}}\right)$ and temperature characteristic $\left(Q_{10}\right)$ for different metabolic processes

\begin{tabular}{|c|c|c|c|c|c|}
\hline Metabolic process & Sample origin & $\begin{array}{c}\text { Temp. range } \\
\left({ }^{\circ} \mathrm{C}\right)\end{array}$ & $\begin{array}{c}E_{\mathrm{a}} \\
\left(\mathrm{kJ} \mathrm{mol}^{-1}\right)\end{array}$ & $Q_{10}$ & Source \\
\hline Oxygen consumption & Microbial mat & 15 to 30 & 55 & 2.35 & Epping \& Kühl (2000) \\
\hline Oxygen consumption & Microbial mat & 25 to 40 & 18 & 1.3 & Wieland \& Kühl (2000) \\
\hline Oxygen consumption & Arctic sediment & 0 to 40 & 39 & 1.8 & Thamdrup \& Fleischer (1998) \\
\hline Oxygen consumption & Coastal sediment & 0 to 50 & 44 to 71 & 1.9 to 3.1 & Thamdrup et al. (1998) \\
\hline Net photosynthesis & Microbial mat & 25 to 40 & 77 & 2.8 & Wieland \& Kühl (2000) \\
\hline Gross photosynthesis & Microbial mat & 25 to 40 & 86 & 3.1 & Wieland \& Kühl (2000) \\
\hline Oxygen consumption & Artificial mat & 0 to 15 & 23 & 1.4 & This study \\
\hline Net photosynthesis & Artificial mat & 0 to 15 & 72 & 3.1 & This study \\
\hline Gross photosynthesis & Artificial mat & 0 to 15 & 60 & 2.6 & This study \\
\hline
\end{tabular}




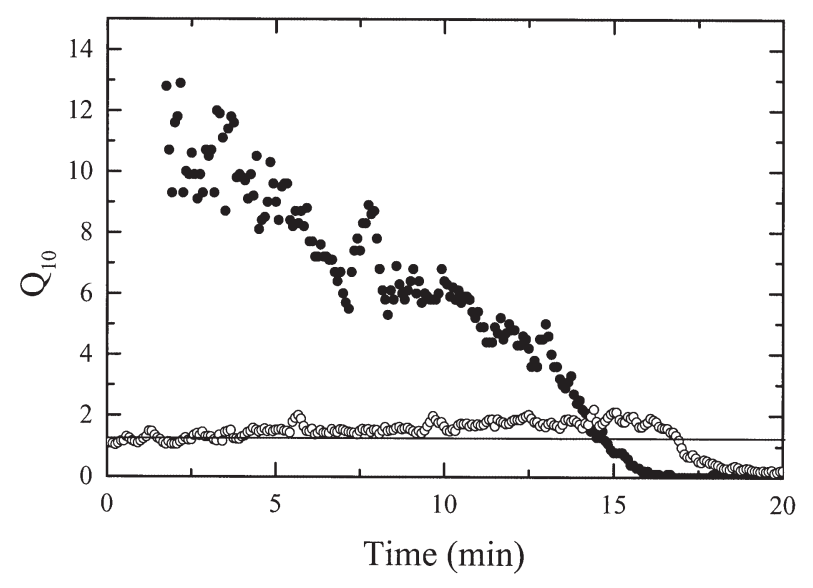

Fig. 7. Time course of apparent $Q_{10}$ value in the photic (o) and the aphotic $(\bullet)$ layers calculated from the dynamics of the dark oxygen respiration presented in Fig. 5. The line represents the $Q_{10}$ value inferred from the steady-state dark oxygen profiles

adapted organisms because this would allow them to maintain a high catalytic efficiency at low temperature. We think that in cold environments, a decrease of $E_{\mathrm{a}}$ is indeed a selective pressure, whereas a decrease of the temperature optimum is probably not selected as such.

In the artificial mat, $E_{\mathrm{a}}$ and $Q_{10}$ values for oxygen consumption were comparable to values found for permanently cold Arctic sediments (Table 1). Therefore, this indicates that the heterotrophic community was adapted to low temperature. Wieland \& Kühl (2000) have explained the low $E_{\mathrm{a}}$ they observed for oxygen consumption in hypersaline mesophilic microbial mats as a limitation of the oxygen transfer from the overlying water to the mat induced by the temperature increase (Wieland \& Kühl 2000). Increase of temperature would have limited the supply of oxygen for the mat, so limiting the oxygen uptake. A similar effect might be also envisaged to partly explain the low $E_{\mathrm{a}}$ found for the oxygen consumption in our study relative to the values found from microbial mats of non-polar environments (Table 1).

Our study confirms that photosynthetic oxygen production is strongly regulated by temperature as previously reported (Davison 1991, Wieland \& Kühl 2000), and contrasts with a recent study indicating that temperature had no effect on gross and net photosynthesis rates (Epping \& Kühl 2000). The apparent $E_{\mathrm{a}}$ and $Q_{10}$ values calculated for gross and net photosynthesis in the artificial mats were comparable to those reported for microbial mats developing in warmer climates (Table 1). Apparently, a significant decrease of $E_{\mathrm{a}}$ has not been achieved for oxygenic photosynthesis in microbial mats, and Antarctic microbial mats seem to be characterised by lower productivity values than their counterparts in warmer climates (Buffan-Dubau et al. 2001). The relatively high $E_{\mathrm{a}}$ for oxygenic photosynthesis might explain that psychrotrophic cyanobacteria reduced their chlorophyll (chl) a content in response to the low photosynthetic capacity at low temperatures (Tang et al. 1997, Tang \& Vincent 1999). This is consistent with the chl $a$ and NP values found for the artificial cold-adapted microbial mats that were lower than those reported for mats in warmer environments (Buffan-Dubau et al. 2001).

\section{Indirect effects of temperature on dark respiration}

Measurements of the respiration dynamics in the dark, calculated from transient oxygen profiles, showed that rates were strongly affected by temperature increase (Figs 4 \& 5). From the respiration dynamics calculated at 0 and $10^{\circ} \mathrm{C}$, we estimated local apparent $Q_{10}$ values for both the photic and aphotic layers, and compared these values to the $Q_{10}$ value calculated for the entire community from the steady-state dark oxygen profiles (Fig. 7). At the beginning of darkness, the apparent $Q_{10}$ value in the aphotic zone was much higher than the $Q_{10}$ value estimated from the steadystate profiles $\left(Q_{10}=1.4\right.$, cf. Table 1$)$. Obviously, in the aphotic zone at $10^{\circ} \mathrm{C}$, the observed decrease of respiration with time related to oxygen depletion (Fig. 5) led to a significant decrease of this apparent $Q_{10}$. The high initial apparent $Q_{10}$ could not be exclusively induced by a direct effect of temperature on the reaction kinetics. We invoke the possibility of migration, which resulted locally in a higher biomass. Increasing temperature enhanced $\mathrm{H}_{2} \mathrm{~S}$ supply by diffusion and probably also by enhancing sulphate reduction, resulting in an increase of the toxic effects of sulphide in the mat. This toxicity could have induced an upwards migration of heterotrophic bacteria and, therefore, in the aphotic zone, the mat could have a higher biomass of heterotrophic bacteria at 10 than at $0^{\circ} \mathrm{C}$, resulting in a higher activity. In addition, most chemotrophic sulphur bacteria are motile and actively follow the oxygen sulphide interface (van Gemerden 1993). Thus, the enhancement of $\mathrm{H}_{2} \mathrm{~S}$ supply with increasing temperature might have stimulated the oxygen requirements for $\mathrm{H}_{2} \mathrm{~S}$ reoxidation. This latter hypothesis was supported by the $\mathrm{H}_{2} \mathrm{~S}$ distribution during the transient states (data not shown): at $0^{\circ} \mathrm{C}$ no $\mathrm{H}_{2} \mathrm{~S}$ was detected at $1.4 \mathrm{~mm}$, whereas incubation at $10^{\circ} \mathrm{C}$ led to $\mathrm{H}_{2} \mathrm{~S}$ accumulation at the same depth upon dark exposure as soon as oxygen was totally depleted. Similar patterns have been suggested to explain the strong stimulation of respiration with temperature increase in natural mesophilic microbial mats (Epping \& Kühl 2000). 
Acknowledgements. This work was financed by the European Union Biotechnology Program through the project MICROMAT, Microbial Diversity of Microbial Mats in Antarctica (contract No. BIO4-CT98-0040). The US Antarctic program has facilitated sampling in the McMurdo Dry Valleys. We sincerely thank Cathy Welch, who collected the microbial mat samples from lake Fryxell, and the Long-Term Ecosystem Research Program (LTER), under whose auspices the material was collected.

\section{LITTERATURE CITED}

Broeker W, Peng T (1974) Gas exchange rates between air and sea. Tellus 26:21-35

Buffan-Dubau E, Pringault O, de Wit R (2001) Artificial coldadapted microbial mats cultured from Antarctic lake samples. 1. Formation and structure. Aquat Microb Ecol 26:115-125

Canfield DE, Des Marais DJ (1993) Biogeochemical cycles of carbon, sulfur, and free oxygen in microbial mat. Geochim Cosmochim Acta 57:3971-3984

Cohen Y, Jørgensen BB, Revsbech NP, Poplawski R (1986) Adaptation to hydrogen sulfide of oxygenic and anoxygenic photosynthesis among cyanobacteria. Appl Environ Microbiol 51:398-407

Davison IR (1991) Environmental effects on algal photosynthesis: temperature. J Phycol 27:2-8

Epping EHG, Kühl M (2000) The responses of photosynthesis and oxygen consumption to short-term changes in temperature and irradiance in a cyanobacterial mat (Ebro Delta, Spain). Environ Microbiol 2:465-474

Epping EHG, Khalili A, Thar R (1999) Dynamics of photosynthesis and respiration in an intertidal biofilm. Limnol Oceanogr 44:1936-1948

Fristen CH, Priscu JC (1998) Cyanobacterial assemblages in permanent ice covers on arctic lakes: distribution, growth rate, and temperature response of photosynthesis. J Phycol 34:587-597

Garcia H, Gordon LI (1992) Oxygen solubility in seawater: better fitting equations. Limnol Oceanogr 37:1307-1312

Hawes I, Schwarz AM (1999) Photosynthesis in an extreme shade environment: benthic microbial mats from lake Hoare, a permanently ice-covered Antarctic lake. J Phycol 35:448-459

Herbert RA, Tanner AC (1977) The isolation and some characteristics of photosynthetic bacteria (Chromatiaceae and Chlorobiaceae) from Antarctic marine sediments. J Appl Bacteriol 43:437-445

Imhoff JF (1995) Taxonomy and physiology of phototrophic purple bacteria and green sulfur bacteria. In: Blankenship RE, Madigan MT, Bauer CE (eds) Anoxygenic photosynthetic bacteria. Kluwer Academic Pulishers, Dordrecht, p 1-14

Isaksen MF, Jørgensen BB (1996) Adaptation to psychrophilic and psychrotrophic sulfate-reducing bacteria to permanently cold marine environments. Appl Environ Microbiol 62:408-414

Johansen JR (1993) Cryptogamic crust of semiarid and arid lands of North America. J Phycol 29:140-147

Jørgensen BB, Cohen Y (1977) Solar Lake (Sinaï). 5. The sulfur cycle of the benthic cyanobacterial mats. Limnol Oceanogr 22:657-666

Knoblauch K, Jørgensen BB (1999) Effect of temperature on sulphate reduction, growth rate and growth yield in five psychrophilic sulphate-reducing bacteria from Arctic sediments. Environ Microbiol 1:457-467
Knoblauch C, Sahm K, Jørgensen BB (1999) Psychrophilic sulfate-reducing bacteria isolated from permanently cold Arctic marine sediments: description of Desulfofrigus oceanense gen. nov., sp. nov., Desulfofrigus fragile sp. nov., Desulfofaba gelida gen. nov., sp. nov., Desulfotalea psychrophila gen. nov., sp. nov. and Desulfotalea arctica sp. nov. Int J Syst Bacteriol 49:1631-1643

Kühl M, Glud RN, Ploug H, Ramsing NB (1996) Microenvironmental control of photosynthesis and photosyntheticcoupled respiration in an epilithic cyanobacterial biofilm. J Phycol 32:799-812

Kühl M, Steuckart C, Eickert G, Jeroschewski P (1998) A $\mathrm{H}_{2} \mathrm{~S}$ microsensor for profiling biofilms and sediments: application in an acidic lake sediment. Aquat Microb Ecol 15: 201-209

Madigan MT, Jung DO, Woese CR, Achenbach LA (2000) Rhodoferax antarcticus sp. nov., a moderately psychrophilic purple non sulfur bacterium isolated from an Antarctic microbial mat. Arch Microbiol 173:269-277

Morita R (1975) Psychrophilic bacteria. Bacteriol Rev 39: $144-167$

Mountfort DO, Rainey FA, Burghardt J, Kaspar HF, Stackebrandt E (1997) Clostridium vincentii sp. nov., a new obligately anaerobic, saccharolytic, psychrophilic bacterium isolated from low-salinity pond sediment of the MacMurdo Ice Shelf, Antarctica. Arch Microbiol 167:54-60

Nadeau TL, Castenholz RW (2000) Characterization of psychrophilic oscillatorians (cyanobacteria) from Antarctic meltwater ponds. J Phycol 36:914-923

Nadeau TL, Howard-Williams C, Castenholz RW (1999) Effects of solar UV and visible irradiance on photosynthesis and vertical migration of Oscillatoria sp. (Cyanobacteria) in an Antarctic microbial mat. Aquat Microb Ecol 20: 231-243

Pierson BK, Oesterle A, Murphy GL (1987) Pigments, light penetration and photosynthetic activity in the multi layered microbial mats of great Sippewissett salt marsh. FEMS Microbiol Ecol 45:365-376

Pringault O, de Wit R, Caumette P (1996) A benthic gradient chamber for culturing phototrophic sulfur bacteria on reconstituted sediments. FEMS Microbiol Ecol 20:237-250

Pringault O, Kühl M, de Wit R, Caumette P (1998) Growth of green sulphur bacteria in experimental benthic oxygen, sulphide, $\mathrm{pH}$ and light gradients. Microbiology 144: 1051-1061

Quesada A, Mouget JL, Vincent WF (1995) Growth of Antarctic cyanobacteria under ultra violet radiationUVA counteracts UVB inhibition. J Phycol 31:242-248

Revsbech N (1989) An oxygen microsensor with a guard cathode. Limnol Oceanogr 34:472-476

Revsbech NP, Jørgensen BB (1983) Photosynthesis of benthic microflora measured with high spatial resolution by the oxygen microprofile method: capabilities and limitations of the method. Limnol Oceanogr 28:749-756

Revsbech NP, Jørgensen BB (1986) Micro-electrodes: their use in microbial ecology. Adv Microb Ecol 9:293-352

Smith REH, Stapleford LC, Ridings RS (1994) The acclimated response of growth, photosynthesis, composition, and carbon balance to temperature in the psychrophilic ice diatom Nitzschia seriata. J Phycol 30:8-16

Tang EPY, Vincent WF (1999) Strategies of thermal adaptation by high-latitude cyanobacteria. New Phytol 142: 315-323

Tang EPY, Tremblay R, Vincent WF (1997) Cyanobacterial dominance of polar freshwater ecosystems: are high-latitude mat-formers adapted to low temperature? J Phycol 33:171-181 
Thamdrup B, Fleischer A (1998) Temperature dependence of oxygen respiration, nitrogen mineralization, and nitrification in Arctic sediments. Aquat Microb Ecol 15:191-199

Thamdrup B, Hansen JW, Jørgensen BB (1998) Temperature dependence of aerobic respiration in a coastal sediment. FEMS Microbiol Ecol 25:189-200

Tindall BJ, Brambilla E, Steffen M, Neumann R and 3 others (2000) Cultivable microbial biodiversity: gnawing at the Gordian Knot. Environ Microbiol 2:310-318

van den Ende FP, van Gemerden H (1994) Relationships between functional groups of organisms in microbial mats. In: Stal LJ, Caumette P (eds) Microbial mats: structure, development and environmental significance. SpringerVerlag, Berlin, p 339-352

van Gemerden H (1993) Microbial mats: a joint venture. Mar Geol 113:3-25

van Gemerden H, Tughan CS, de Wit R, Herbert RA (1989)

Editorial responsibility: Karin Lochte,

Rostock, Germany
Laminated microbial ecosystems on sheltered beaches in Scapa flow, Orkney Islands. FEMS Microbiol Ecol 62: 87-102

Vincent FW, Castenholz RW, Downes MT, Howard-Williams C (1993) Antarctic cyanobacteria: light, nutrients, and photosynthesis in the microbial mat environment. J Phycol 29:745-755

Wieland A, Kühl M (1999) Short-term temperature effects on oxygen and sulfide cycling in a hypersaline cyanobacterial mat (Solar Lake, Egypt). Mar Ecol Prog Ser 196:87-102

Wieland A, Kühl M (2000) Irradiance and temperature regulation of oxygenic photosynthesis and $\mathrm{O}_{2}$ consumption in a hypersaline cyanobacterial mat (Solar Lake, Egypt). Mar Biol 137:71-85

Wynn-Williams DD (1996) Response of pioneer soil microalgal colonists to environmental changes in Antarctica. Microb Ecol 31:177-188

Submitted: February 26, 2001; Accepted: October 5, 2001 Proofs received from author(s): November 27, 2001 